\title{
Rolling of magnesium
}

\author{
佐藤 雅彦 $*$ \\ Masahiko SATO*
}

\section{1. マグネシウムの圧延}

板圧延工程とは，金属材料を回転するロールと呼ばれる円 筒形工具間を通過させ，板厚を薄くする工程である。材料の 変形形態は，ロールによる連続的な圧縮変形といえる。圧延 には熱間圧延と冷間圧延があり，マグネシウムは工業生産的 な冷間圧延が不可能であるために，粗圧延から仕上げ圧延ま でのすべての工程が約 $200^{\circ} \mathrm{C}$ 以上の熱間で行われる。これは マグネシウム板材独特の集合組織と变形機構によるものであ るが，この点がマグネシウム合金板材の発展を遅らせた原因 といえる。現在では，マグネシウム合金の優れたホットコイ ル製造方法と熱間圧延技術が開発され，市場においてもその 成形体が好評を博すまでになった。マグネシウムの圧延品は， 高い表面性状と高比剛性率を利用した携帯用電子機器笚体に 使用が拡大しつつある。

\section{2. 製造工程と設備構成}

\section{1 圧延に使用されるマグネシウム合金}

マグネシウム合金は ASTM による表示が国際的に通用して いる ${ }^{1)}$ 。なかであ圧延に用いられる展伸用合金は， AZ $(\mathrm{Mg}$
$\mathrm{Al}-\mathrm{Zn})$ 系，ZK（Mg-Zn-Zr）系合金などが規格化されてお り，図 1 に示す規則によって，主な添加元素とその添加量が 表示される。表 1 に ASTM B90 における AZ31B 合金の化学 組成規格を示す。また，JIS においても JIS H 4210 に規定され ている。表 2 にマグネシウム合金板および条の JIS 記号とそ れに対応する他の規格での相当合金および主な用途を示し， 表 3 にはそれぞれの化学成分規格を示す。展伸材は，圧延， 押出，鍛造などに用いられ，実際の使用量の大半を AZ 系合 金が占める。その中であ $\mathrm{AZ} 31$ 合金（JISの MP1 相当 $\mathrm{Al}$ ： $3 \%, \mathrm{Zn} ： 1 \%$ ）は成形性，強度，価格のバランスに優れ， 圧延材として最も多く使用されている。表 4 に AZ31B 合金 の製品の代表的レードル值（溶湯分析值）を示す。圧延板材

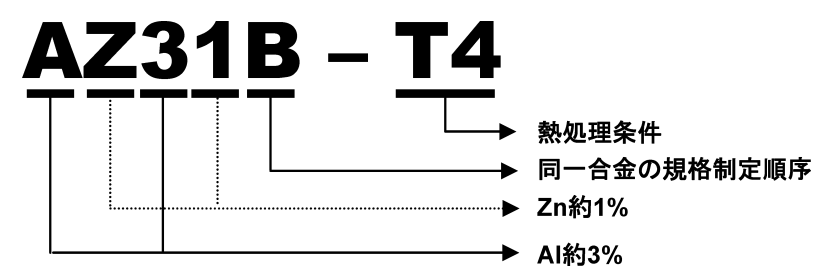

図 1 マグネシウム合金の表示

表 1 ASTM B90/B90M における AZ31B マグネシウムの化学組成規格

\begin{tabular}{c|c|c|c|c|c|c|c|c|c|c|c}
\hline \hline \multirow{2}{*}{\begin{tabular}{c} 
記号 \\
\cline { 2 - 15 }
\end{tabular}} & $\mathrm{Al}$ & $\mathrm{Zn}$ & $\mathrm{Mn}$ & $\mathrm{Fe}$ & $\mathrm{Si}$ & $\mathrm{Cu}$ & $\mathrm{Ni}$ & $\mathrm{Ca}$ & $\mathrm{RE}$ & $\mathrm{Zr}$ & $\mathrm{Mg}$ \\
\hline $\mathrm{AZ31B}$ & $2.5 \sim 3.5$ & $0.6 \sim 1.4$ & $0.2 \sim 1.0$ & 0.005 以下 & 0.10 以下 & 0.05 以下 & 0.005 以下 & 0.04 以下 & - & - & \multirow{2}{*}{ Bal. } \\
\hline
\end{tabular}

表 2 マグネシウム合金および条の種類および記号

\begin{tabular}{|c|c|c|c|c|c|c|c|}
\hline \multirow{2}{*}{ 種類 } & \multirow{2}{*}{ 記号 } & \multirow{2}{*}{ 対応 ISO 記号 } & \multicolumn{4}{|c|}{ 相当合金（参考） } & \\
\hline & & & ASTM & BS & DIN & $\mathrm{NF}$ & \\
\hline 1 種 B & MP1B & ISO-MgAl $\mathrm{Zn}_{1}$ (A) & AZ31B & MAG110 & 3.5312 & G-A3Z1 & 成形用，電極板など \\
\hline 1 種 C & MP1C & ISO- $\mathrm{MgAl}_{3} \mathrm{Zn}_{1}$ (A) & - & - & - & - & 食刻板，印刷板など \\
\hline 7 種 & MP7 & - & - & - & - & - & 成形用，食刻板，印刷板など \\
\hline 9 種 & MP9 & ISO-MgZn ${ }_{2} \mathrm{Mn}_{1}$ & - & MAG131 & - & - & 成形用など ～～～～～～～～ \\
\hline
\end{tabular}

* 日本金属㑣）（干 108-0014 東京都港区芝 5-30-7)。 NIPPON KINZOKU CO., LTD. (5-30-7 Shiba, Minato-ku, Tokyo 108-0014)。

受付日：平成 21 年 7 月 1 日 受理日：平成 21 年 8 月 5 日 


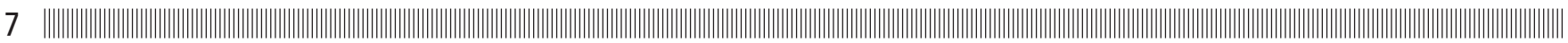

表 3 マグネシウム合金板および条の化学成分

$(\operatorname{mass} \%)$

\begin{tabular}{|c|c|c|c|c|c|c|c|c|c|c|c|c|}
\hline \multirow[b]{2}{*}{ 種類 } & \multirow[b]{2}{*}{ 記号 } & \multicolumn{11}{|c|}{ 化学成分 } \\
\hline & & $\mathrm{Al}$ & $\mathrm{Zn}$ & $\mathrm{Mn}$ & $\mathrm{Fe}$ & $\mathrm{Si}$ & $\mathrm{Cu}$ & $\mathrm{Ni}$ & $\mathrm{Ca}$ & $\begin{array}{l}\text { その他 } \\
\text { の元素 }\end{array}$ & $\begin{array}{l}\text { その他 } \\
\text { の元素 } \\
\text { の合計 }\end{array}$ & $\mathrm{Mg}$ \\
\hline 1 種 B & MP1B & $2.4 \sim 3.6$ & $0.5 \sim 1.5$ & $0.15 \sim 1.0$ & 0.005 以下 & 0.10 以下 & 0.05 以下 & 0.005 以下 & 0.04 以下 & 0.05 以下 & 0.30 以下 & Bal. \\
\hline 1 種 C & MP1C & $2.4 \sim 3.6$ & $0.5 \sim 1.5$ & $0.05 \sim 0.4$ & 0.05 以下 & 0.1 以下 & 0.05 以下 & 0.005 以下 & - & 0.05 以下 & 0.30 以下 & Bal. \\
\hline 7 種 & MP7 & $1.5 \sim 2.4$ & $0.5 \sim 1.5$ & $0.05 \sim 0.6$ & 0.010 以下 & 0.10 以下 & 0.10 以下 & 0.005 以下 & - & 0.05 以下 & 0.30 以下 & Bal. \\
\hline 9 種 & MP9 & 0.1 以下 & $1.75 \sim 2.3$ & $0.6 \sim 1.3$ & 0.06 以下 & 0.10 以下 & 0.10 以下 & 0.005 以下 & - & 0.05 以下 & 0.30 以下 & Bal. \\
\hline
\end{tabular}

表 4 代表的な AZ31B マグネシウムのレードル分析值（単位：mass\%)

\begin{tabular}{|c|c|c|c|c|c|c|c|c|c|}
\hline 区分 & $\mathrm{Al}$ & $\mathrm{Zn}$ & $\mathrm{Mn}$ & $\mathrm{Ca}$ & $\mathrm{Si}$ & $\mathrm{Fe}$ & $\mathrm{Cu}$ & $\mathrm{Ni}$ & Others \\
\hline $\begin{array}{l}\text { 実績 } \\
\text { AZ31B }\end{array}$ & $\begin{array}{c}3.02 \\
2.5 / 3.5\end{array}$ & $\begin{array}{c}0.95 \\
0.6 / 1.4\end{array}$ & $\begin{array}{c}0.4 \\
0.2 / 1.0\end{array}$ & $\begin{array}{c}0.02 \\
\leqq \\
0.04\end{array}$ & $\begin{array}{c}0.02 \\
\leqq \\
0.10\end{array}$ & $\begin{array}{c}0.003 \\
\leqq 0.005\end{array}$ & $\begin{array}{l}0.002 \\
\leqq 0.05\end{array}$ & $\begin{array}{l}0.0004 \\
\leqq 0.005\end{array}$ & $\leqq 0.30$ \\
\hline
\end{tabular}

は，主にプレス成形用途として使用されるが，鋳造を基本と したダイカスト品と比較して表面欠陥が少なく，外装筐体に 用いられる場合が多い。さらに素材肌を活かした薄い塗装処 理を行うような，高意匠面に用いられる場合が多い。このこ とから，表面処理性と耐食性を維持するために， $\mathrm{Fe}, \mathrm{Ni}, \mathrm{Cu}$ 等の不純物は特に厳重に管理する必要がある。また近年では, 高合金系 $\mathrm{AZ}$ 合金の圧延材む製作されるようになってきた。 これは, さらなる高強度化と高耐食性, および表面処理の容 易さ等への期待によるもので，基本的には $\mathrm{Al}$ 添加量の多い $\mathrm{AZ61}(\mathrm{Al}: 6 \%, \mathrm{Zn}: 1 \%)$ や, AM60 (Al : 6\%, Mn : 0.3\%), AM50 ( $\mathrm{Al}: 5 \%, \mathrm{Mn}: 0.3 \%$ ) が主である。

これら $\mathrm{AZ}$ 系合金のほかに， Mg-Li 系合金も圧延素材とし て用いられている。 $\mathrm{Mg}$ に $6 \%$ 以上の $\mathrm{Li}$ を添加すると体心立 方晶の $\beta$ 相 ${ }^{2)}$ が析出し, 冷間成形性が著しく改善される。さ らに $12 \%$ 以上の $\mathrm{Li}$ を添加すると $\beta$ 単相合金となって，さら に冷間成形性が良好になる。一般的には， Mg-Li 合金に $\mathrm{Al}$ やZn を添加して使用される。この合金の ASTMによる表示 は， $\mathrm{Al}$ 添加合金は LA， Zn 添加合金は LZ である。

\section{3. 圧延とは}

圧延は，圧延機などを用いて板厚を薄くする工程である。 被圧延材である板材は摩擦力によって二つのロール間に引込 まれ，板厚方向に圧縮されて，目標の板厚まで板厚が減少す る。図 2 に模式図を示すが，このときのロールと板が接触し ているロール円弧の長さを接触弧長, その圧延方向長さを投 影接触長さ $L_{\mathrm{d}}$ という。板圧延の加工度は圧下率 $r$ (リダク ション）で表され, 圧延前の板厚 $h_{0}$, 圧延後の板厚 $h_{1}$ を用 いて次式で与えられる。

$$
r=\frac{h_{0}-h_{1}}{h_{0}} \times 100(\%) \quad h_{0}-h_{1}: \text { 压下量 }
$$

また，ロール周速が一定の場合，板速度はロール入口から

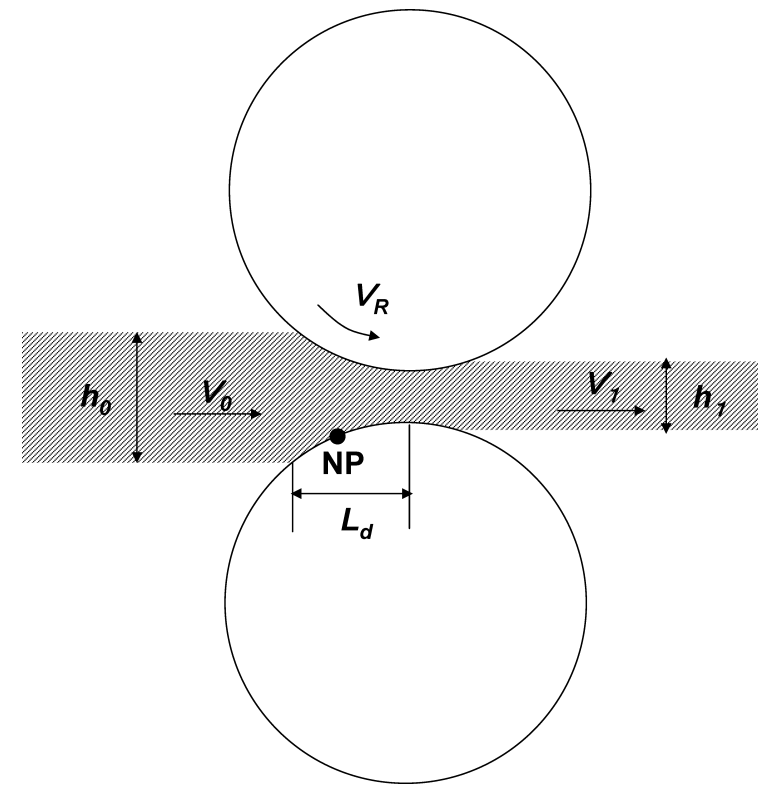

図 2 圧延によるロール間での変形

出口に向かって速くなる。そして入口から出口に至る接触弧 長内でロールの周速 $V_{\mathrm{R}}$ と等しくなる点がある。これを中立 点 NP と呼ぶ。この中立点前後ではロールと板との相対速度 が逆となる。すなわち, 中立点より入り側では板はロールよ り遅れ, 出口では先進 (増速) する。

このように，板は圧延によって板厚方向に圧縮されるが， これに応じて圧延方向に伸びる。圧延後の長さは圧縮前の長 さのほぼ $h_{0} / h_{1}$ で示すことができる。厳密には異なるが，こ

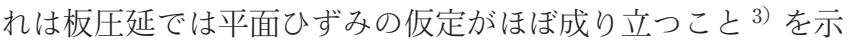
している。 


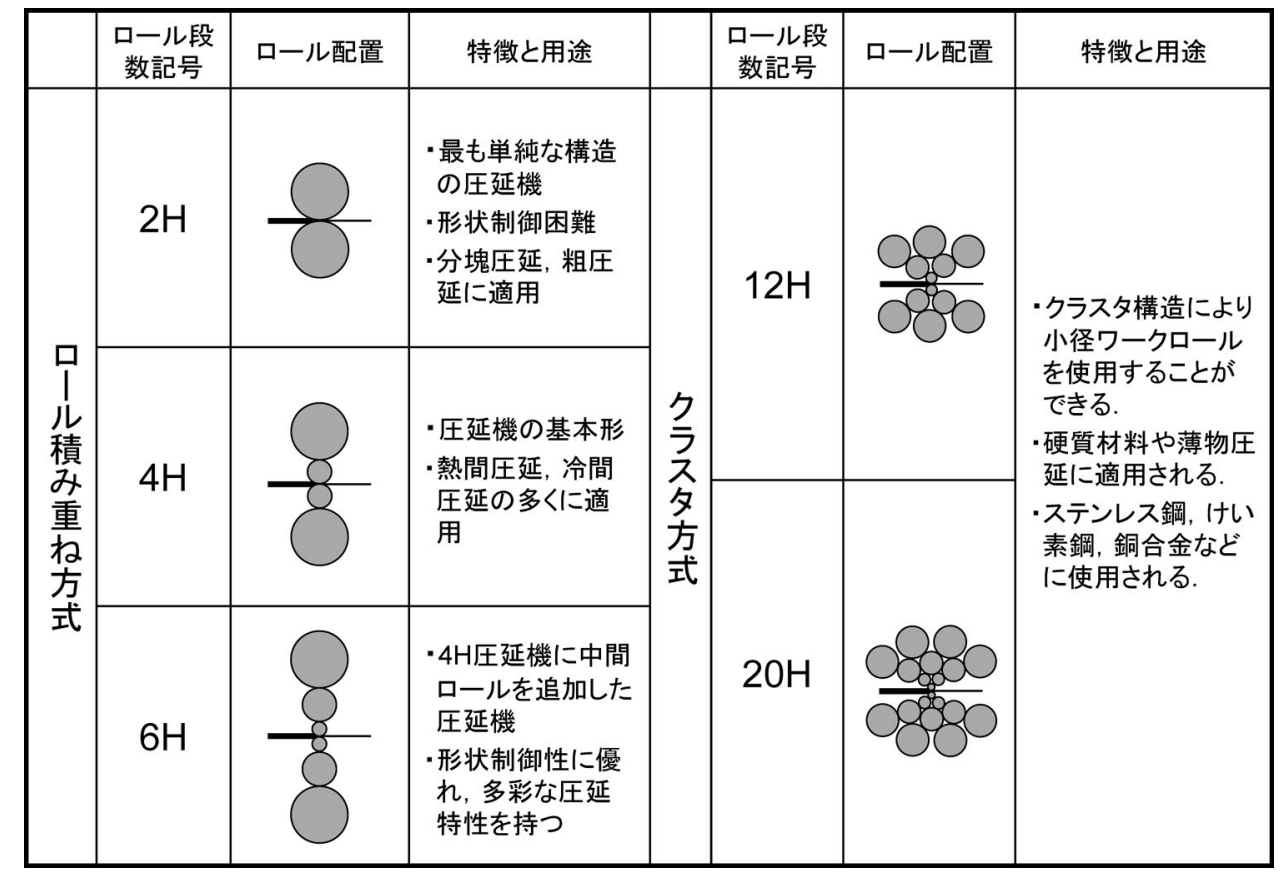

図 3 圧延機で採用されているロール配置

\section{4. 圧延機}

\section{1 圧延機の分類}

圧延製品の種類は多く，これらが多数の工程を経て製造さ れるため，圧延機の種類も多種多様なものになっている。こ れらの圧延機は構造あるいは適用法の違いによって分類する ことができる。

\section{2 圧延機を構成するロールの段数}

圧延機の構造面加らの最む基本的な分類は，ロールの段数 で行われる。ロール段数は図 3 に示されるように最む単純な 2 段ロール圧延機から，主に銅合金やステンレス鋼の压延に 用いられる 20 本のロールで構成される 20 段圧延機まで多岐 にわたる ${ }^{4)}$ 。一般に，ロールの段数が増加するのは，圧延さ れる材料の特性や必要之される板厚によるあので, 加工硬化 の大きい材料や，箔などの薄物材料ほど多段圧延機が使用さ れる。マグネシウムの压延に用いられる圧延機は 2 段から 6 段圧延機が多い。これはマグネシウムが工業生産として冷間 圧延できないことに起因しており, 熱間圧延中の加工硬化が 小さいことと, 圧延効率よりもむしろ形状制御性や，圧延中 の温度保持性を重視して選択されるからである。

\section{3 板形状制御}

圧延板材では，平坦度（フラットネス）やクラウン等の形 状制御（プロフィール）を行う必要がある。クラウンは幅方 向の板厚偏差のことで, 形状ばかりでなく, 絶対值は板厚精 度にも影響を与える重要なものである。図 4 に代表的な板ク ラウンの例を示すが，クラウンは原料コイルのクラウンが仕 上げ压延品のクラウンにまで影響を与えるため, 実際には全 工程において管理するべき項目である。圧延機におけるクラ ウンの発生要因は複数考えられるが, 主に, (1)圧延ロールの 弾性変形，(2) ヒートクラウン等が要因となる。これら板クラ

\begin{tabular}{|c|c|c|}
\hline 名 称 & 特 徵 & 外 観 \\
\hline フラット & $\begin{array}{l}\text { 幅方向に均一な板 } \\
\text { 厚分布 }\end{array}$ & \\
\hline 凸クラウン & $\begin{array}{l}\text { 板幅中央部が厚い } \\
\text { 板厚分布 }\end{array}$ & \\
\hline 凹クラウン & $\begin{array}{l}\text { 板厚中央部が薄い } \\
\text { 板厚分布 }\end{array}$ & \\
\hline ウェッジ & 幅方向で片テーパ & \\
\hline 複合クラウン & $\begin{array}{l}\text { 幅方向でニつ以上 } \\
\text { の凸クラウンを持つ } \\
\text { 板厚分布 }\end{array}$ & \\
\hline
\end{tabular}

図 4 板クラウンの種類の模式図

ウンの制御方法として，あらかじめロールのたわみを予測し て, ロールを研磨して压延ロールの形状を変化させて押く, イニシャルロールクラウン制御がある。この方法はほぼすべ ての圧延機において一般的に行われているあので, 特にロー ル段数の少ない 2 段圧延機などでは重要な方法である。正確 な制御を行うためには, 圧延荷重に伴うロールの弾性変形量 を正確に把握する必要がある。

4 段以上の圧延機ではロールベンディング装置やロールクー ラントスプレーによる制御が行われる。図 5 に主な形状制御 


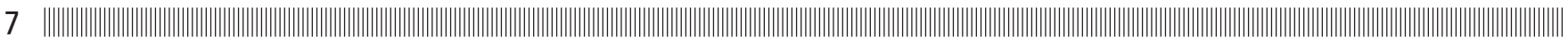

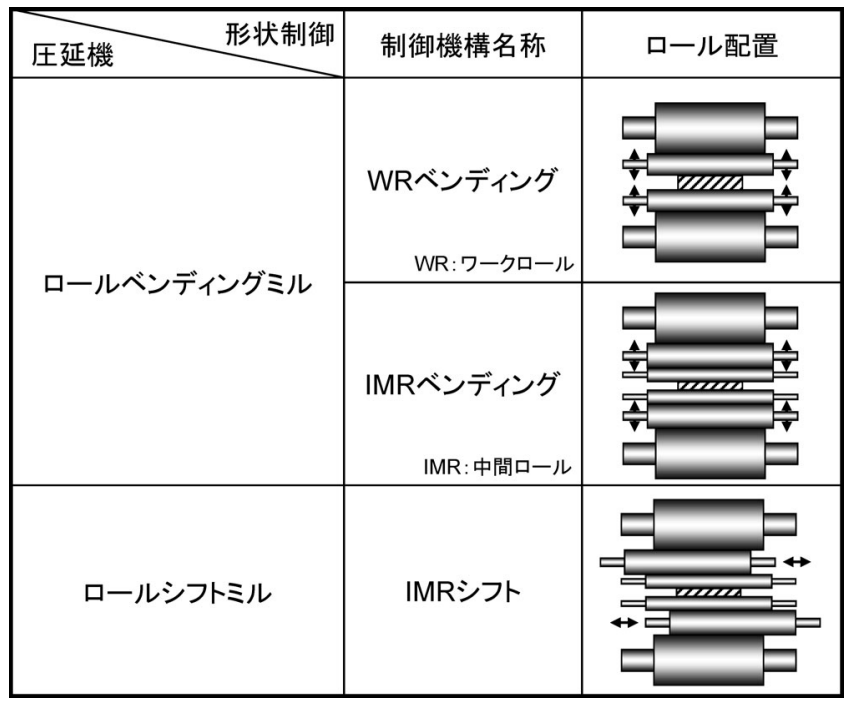

図 5 圧延機で用いられている主な形状制御機構

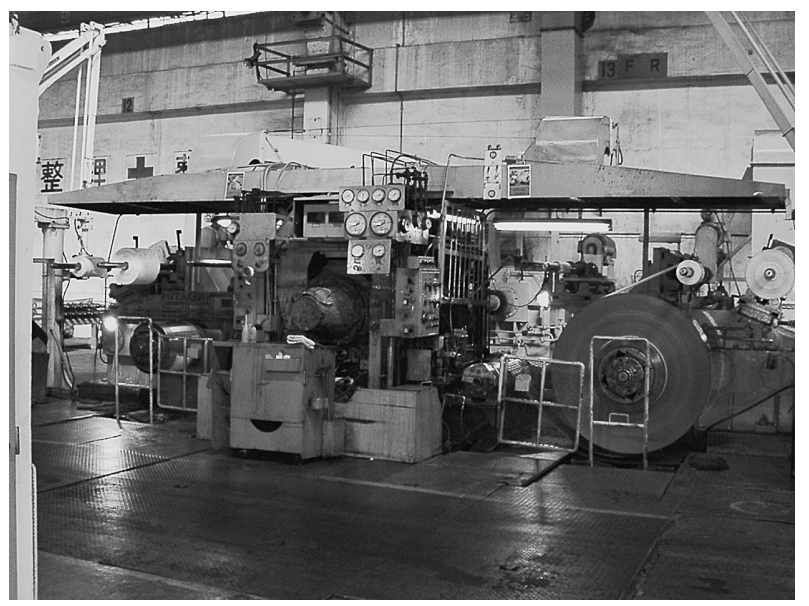

図 6 可逆式四段圧延機の一例

機構を示すが，ロールベンディング装置とは，油圧装置を用 いて主にワークロールをたわませるあのであって，イニシャ ルクラウン制御と併用される。ロールベンディング装置には, 油圧シリンダを複数配し，上り多くのたわみを与えられるよ うにしたベンダあある。図 6 に可逆式 4 段圧延機の一例を示 す。6段以上の圧延機の場合は中間ロールを有するために, この中間ロールに主にテーパを付けて，幅方向にシフトさせ る中間ロールシフトあ用いられる。中間ロールのテーパ量や 端部からの深度を変化させることで制御幅を变化させること ができる。このような圧延機は UC ミルもしくは HCミルと 呼ばれる。

クラスタタイプの圧延機もマグネシウムに適用可能である。 図 7 に代表的なクラスタタイプミルである 20 段圧延機八ウ ジング部の外観を示す。しかしながら，LZ，LA 合金や AZ 系合金簿材の仕上げ圧延など限定的な適用がほとんどである。 このクラスタタイプの圧延機は, 特に薄物の圧延に扔いて高 い形状制御性を有しており，中間ロールシフトや，ASU と呼 ばれる分割偏心バックアップロール制御を用いることができ る。これらを最大限利用することで，SUSに执いて $0.002 \mathrm{~mm}$

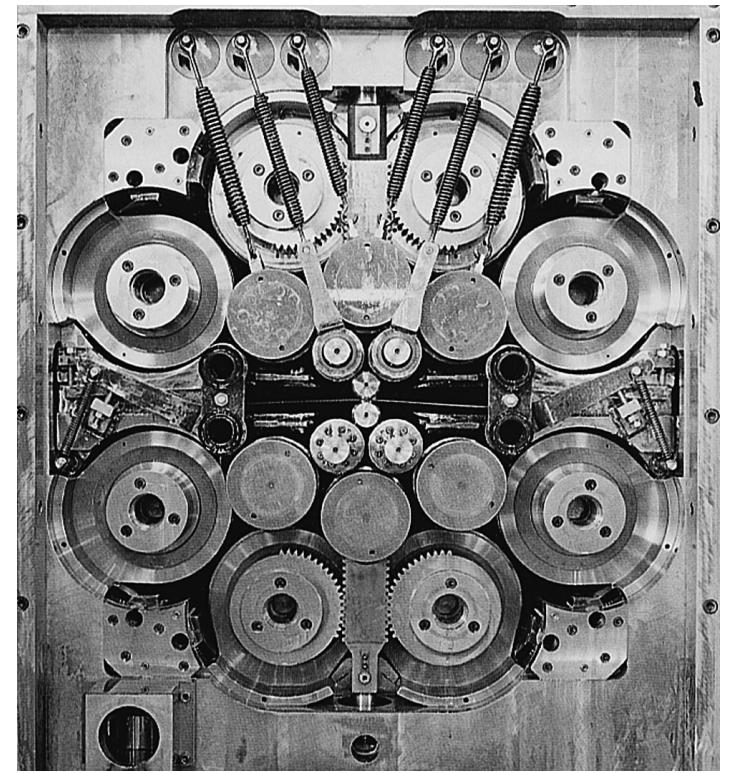

図 7 可逆式 20 段圧延機のロール配置例

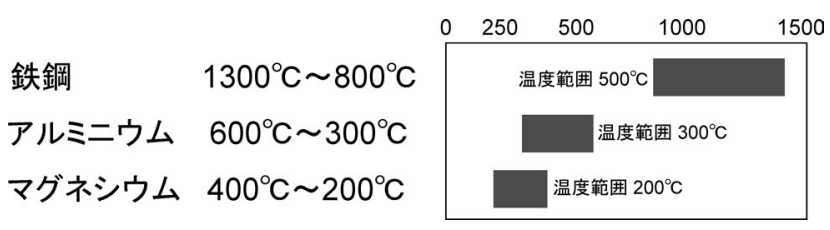

図 8 各種実用材料の熱間圧延温度範囲の比較

厚で幅 $700 \mathrm{~mm}$ のコイル材圧延も行われている。マグネシウ ムにおいてあ，0.1 mm 以下の箔材試作圧延に用いられた実績 あある。

このように, 圧延機にはタイプ別に複数の形状制御技術が 投入されているが，これらは万能ではない。もともと矩形断 面をもつスラブから圧延を行った場合, 薄い部分は厚い部分 に比べて長くなるために平坦度が覀化する。現実的には，幅 方向に複数幅で切断し製品とする多条取りを行う場合や，後 に行われる形状矯正工程の効果を考慮した形状の作り込みが 必要であり，この点においては，マグネシウムと他金属との 間に違いはない。

\section{4 温度管理}

前述のようにマグネシウムの圧延は, 分塊から仕上げまで のすべての圧延工程が熱間で行われる。このために, 圧延材 の温度管理が非常に重要である。温度管理は平坦度制御だけ でなく, 圧延の可否自体を大きく左右する。図 8 亿鉄, アル ミニウムとの圧延温度打よび範囲の違いを示すが，マグネシ ウムは工業生産的に必要な圧延下限温度が $200^{\circ} \mathrm{C}$ 近傍で, 圧 延材の機械的特性を考慮すると圧延に使用できる温度範囲は $200 \sim 400^{\circ} \mathrm{C}$ と $200^{\circ} \mathrm{C}$ 程度の幅しかない ${ }^{2}$ 。このような温度範 囲を実現するために製造工程には各種の工夫がなされている。 量産工程の情報公開はまったくと言っていいほどなされてい ないために詳細は不明であるが，スラブ等被圧延材はあらか じめ加熱炉内で加熱され压延に供される場合が多い。また， ロールを加熱する場合あある ${ }^{6)}$ 。報告されているロール加熱 法はカートリッジヒー夕等をあらかじめロール内に組込み, 
給電ブラシなどで給電してロールを加熱するものである。概 念図を図 9 に示す。被圧延材と直接接する圧延ロールへの抜 熱は大きく，ロールを加熱することでマグネシウム合金の温 度低下が抑制され，1回の加熱で大きな総合圧下率を与える ことが可能となる。しかしながら，高温に積極的に加熱され たロールで圧延する場合, 圧延効率は高くなるが, 反面, 潤 滑が非常に困難となる。マグネシウムは特に熱間圧延時に ロールへの凝着（ピックアップ）が生じやすく, 表面品質に 悪影響を及ぼす。鑓田らはマグネシウムの圧延における潤滑 油の有効性を評価している ${ }^{7)}$ 。図 10 に圧延潤滑条件を変化 させた場合のロール表面への影響を示す。潤滑油を用いるこ とで凝着を軽減でき，特に合成油使用の効果が高いとしてい る。ロール表面の粗さにおいても, 合成油が最む小さい。ま

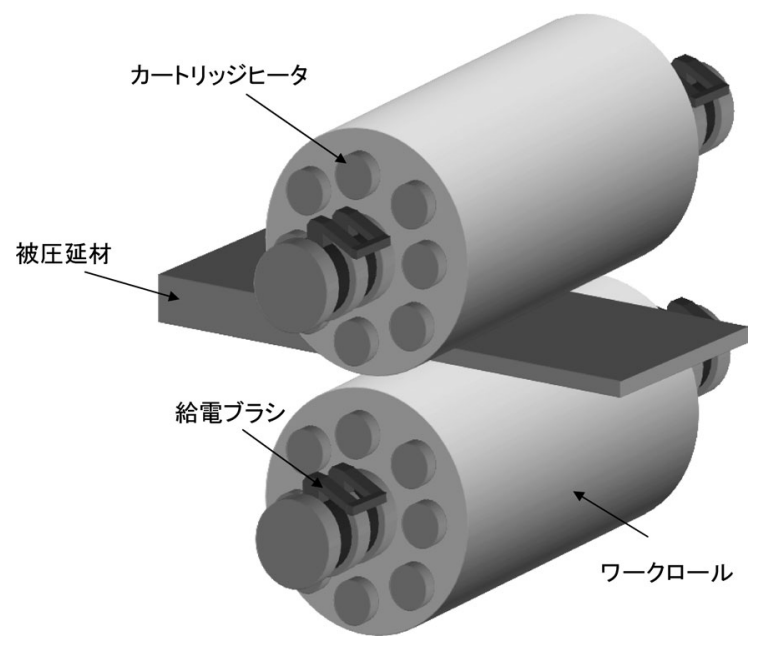

図 9 ヒータによる加熱ロール例（模式図）
た，このピックアップを防止するために多量の圧延油を用い る場合がある。いまだ有効な圧延油がないばかりか, 炭化し た圧延油が板材表面に押込まれて, やはり表面品質に悪影響 を与える。

形状の面では, 形状制御性の高い多段圧延機ほど材料と ロール間のみならず，ロール／ロール間の熱伝導や潤滑も考 慮する必要がある。このようにロール数が増加すると温度分 布が複雑になるため, 温度分布変化を考慮したロールクラウ ンと形状制御装置の適用範囲の検討が必要となる。

\section{5. マグネシウム圧延材の製造工程}

マグネシウム合金圧延板材の製造工程の一例を図 11 に示 す。所定の成分調整を行ったマグネシウム合金溶湯から種々 の方法でホットコイルを製造し, 仕上げ圧延を経て幅切断, 表面仕上げを行い, 製品コイルとなる。以下に各工程の現状 とポイントを示す。

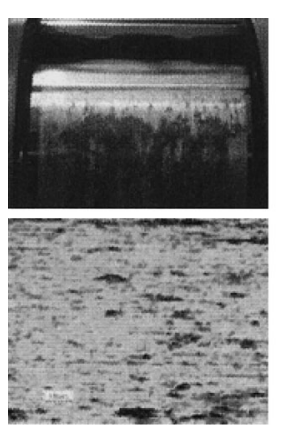

無潤滑 $\mathrm{Ra}=0.177 \mu \mathrm{m}$
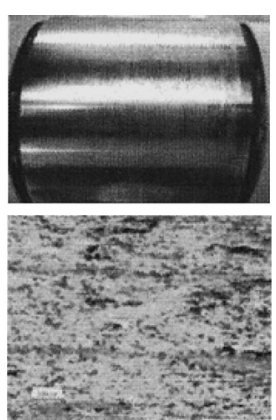

鉱物油

$\mathrm{Ra}=0.125 \mu \mathrm{m}$
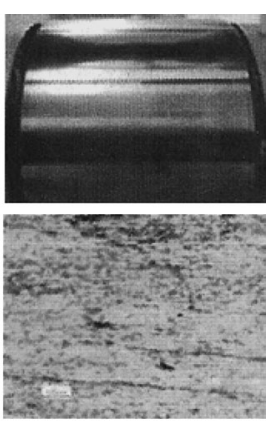

合成油

$\mathrm{Ra}=0.103 \mu \mathrm{m}$
図 10 潤滑油の及ぼすロールおよび被圧延材表面への影響

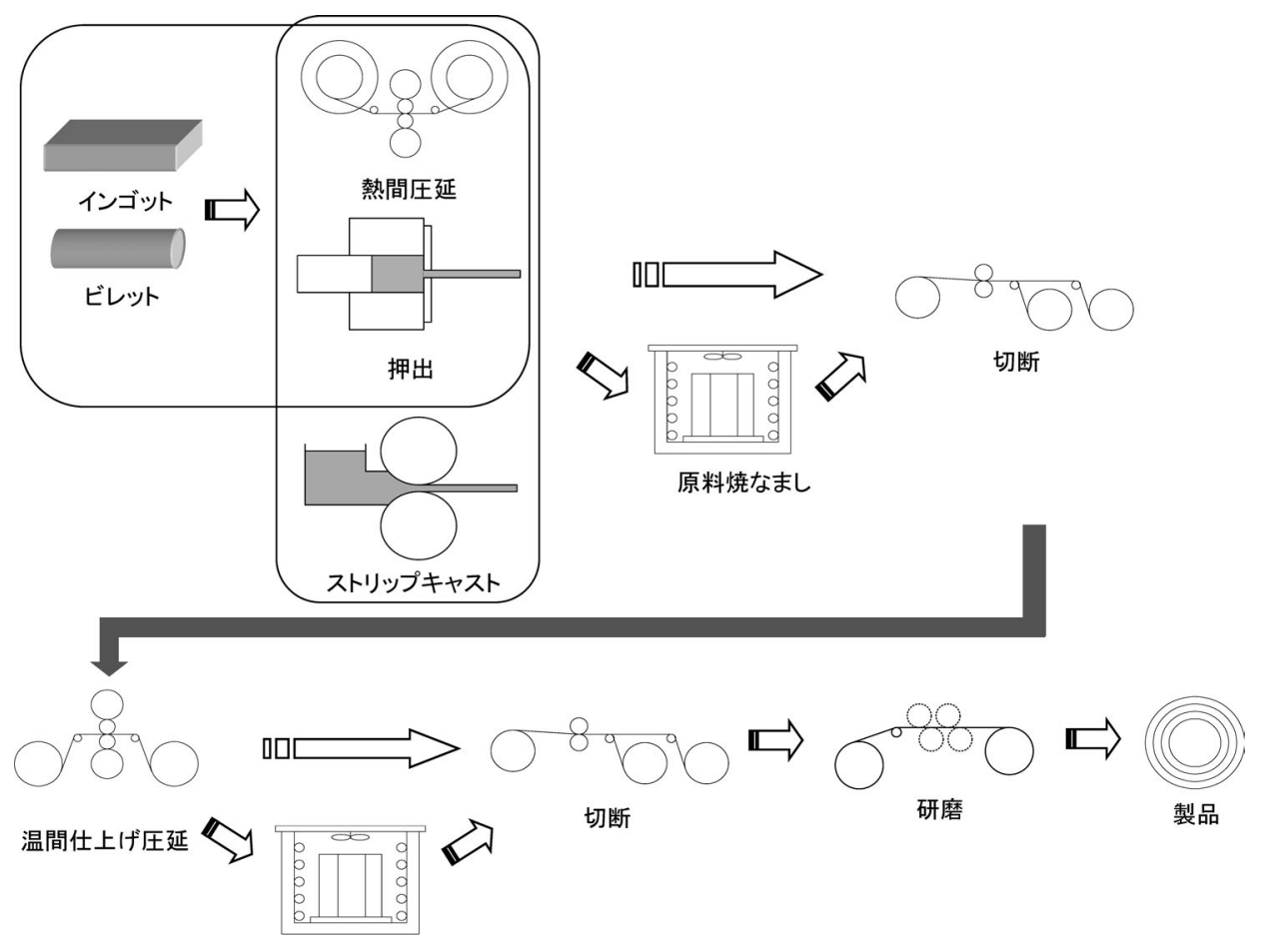

製品焼なまし

図 11 マグネシウム合金圧延板材の製造工程例 


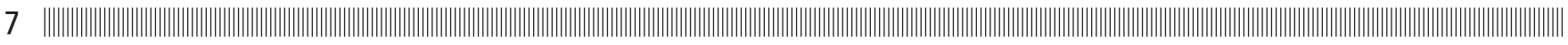

\section{1 母材コイルの形態}

板圧延を行うためには，まず母材となるホットコイルを得 る必要がある。その方法としてスラブ圧延法, 押出法, スト リップキャスト法が現在実用化されている。工業的なマグネ シウムの圧延はまだ歴史が浅く，これらの方法の中から，コ スト・サイズ・品質面を考慮して選択される。

\section{2 スラブ圧延法}

スラブ圧延法は, 重力鋳造法や半連続鋳造（DC）法など により矩形断面の大型インゴットを製作し，熱間圧延機の仕 様に合せて切出したスラブを熱間圧延してホットコイルを製 造するものである。原料となるマグネシウム合金インゴット は，海外メ一カに扔いて約 127 305 mm 厚 ×406 1041 mm 幅 の矩形 DC (半連続鋳造) スラブが製造されて ${ }^{8)}$ おり，ドイ ッやカナダでは $1000 \mathrm{~mm}$ 幅を超える板材が製造・販売されて いる。

日本国内においても， $900 \mathrm{~mm}$ 幅の板材の試作例があるが, 現在量産品として確認できる压延用途のスラブは，図 12 に 示す $150 \mathrm{~mm}$ 厚 $\times 600 \mathrm{~mm}$ 幅（最大 $750 \mathrm{~mm}$ 幅）のスラブか,

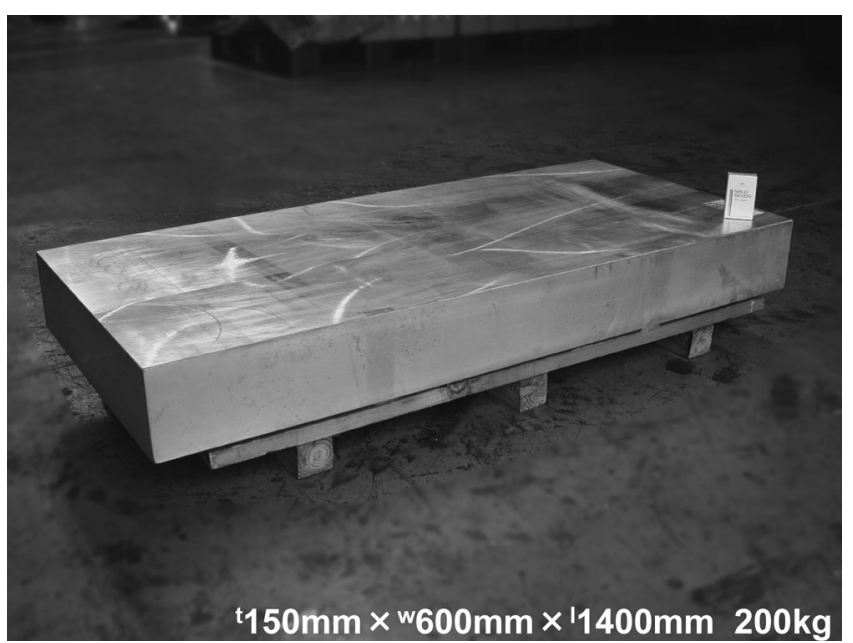

図 12 圧延用マグネシウム合金スラブ外観
16 インチ直径の円形断面を持つ DC ビレットをスライスした あのである。

このスラブの品質は，圧延材に直接大きな影響を与えるた めに，まず良質なスラブを得ることが重要となる。マグネシ ウムは溶湯内の不純物元素より比重が小さいため, これを炉 底に沈降させ分離する場合が多いが, 不純物元素之の比重差 が小さく, 多くの時間を要する。このため, 溶解炉のほかに 静置炉，保持炉を区別して使い分けている ${ }^{9)}$ 。しかしながら， 鋳造時には不純物を巻込みやすく注意が必要である。前述の 通り, マグネシゥム合金のスラブは, 主に重力鋳造か半連続 鋳造によって製造されている。マグネシウムの重力鋳造は鉄 製鋳型を用いて行わ机るが，表面近傍に生成した酸化物層や 不純物層を除去するために表面研削が行わ机る。この点につ いてはアルミニウムなどと同様である。その後, 均質加熱処 理が行われる。例えば AZ31 合金では $400^{\circ} \mathrm{C}$ 以上で 24 時間程 度の均質加熱処理が行われる場合が多い。これは凝固時に生 じた固溶元素の析出物や偏析を均質化することが目的であっ て, AZ61等の合金元素添加量の多い合金ではさらに長時間 熱処理される場合がある。半連続鋳造はモールドで表面が㠜 固した直後に水冷されるため, 冷却速度が速く, 単相合金の 場合, サイズによっては均質加熱処理が省略される場合もあ る。

このようにして製造したスラブは，熱間圧延によってホッ トコイルとなるが，圧延工程にはシートタイプの圧延機か， このシートタイプの圧延機にファーネスコイラと呼ばれる, 保温機能を有するリール設備を組合せたステッケルタイプの 圧延機が使用される。図 13 亿熱間圧延工程に使用される圧 延機の組合せ例を示す。熱間圧延は再結晶温度以上で行われ るが, 他の熱間圧延を行う材料, 例えば鉄鋼材料やアルミ二 ウムと比較して圧延温度範囲が狭く, 場合によっては耳割れ や板切れが生じ, 安定操業を困難なむのとしている。

\section{3 押出法}

押出法は，むともとアルミニウムサッシなどで実用化され た技術を応用し，マグネシウム合金の板材に応用したもので

\begin{tabular}{|c|c|c|}
\hline & 圧延機配置 & 特徵 \\
\hline 厚板 & & $\begin{array}{l}\text { ·粗, 仕上げ用の二基の } \\
\text { 可逆圧延機でシートを圧 } \\
\text { 延する場合. } \\
\text { ·主に厚板に用いられる. } \\
\text { ·設備が安価. }\end{array}$ \\
\hline 可逆式 & & $\begin{array}{l}\text { ·可逆式仕上げ压延機一 } \\
\text { 基でスラブからホットイイ } \\
\text { ルまで圧延する場合. } \\
\text { ·加熱·保温機能を持つ } \\
\text { リールを有する. }\end{array}$ \\
\hline 粗+可逆式 & & $\begin{array}{l}\text { ·それぞれー基の可逆式 } \\
\text { 粗圧延機と可逆式仕上げ } \\
\text { 圧延機の組合せ. } \\
\text { ·生産の自由度が高い. }\end{array}$ \\
\hline
\end{tabular}

図 13 マグネシウム合金熱間圧延設備の組合せ例 
ある ${ }^{10)}$ 。原料となるビレットは，溶解・精錬方法が異なる が，アルミニウムと同様の DC 鋳造機を用いて製造可能であ る。押出設備についてもアルミニウムとマグネシウムは共用 が可能である。得られる板材の表面品質は高く, 表面欠陥や 耳割れのない良好な製品が得られている。また，金型サイズ の变更により, 幅や板厚の選択の自由度が高いこともこの方 法の特徴の一つである。スラブ圧延法やストリップキャスト 法では必要となる, 原料切断工程の省略が可能となることで 歩留まりの向上が望める。しかしながら問題点として, 押出 設備の構造上の制限から，板幅および板長さに制限がある。 すなわち，押出機の能力（押出圧力）によって決定されるビ レット径に伴う板幅の制限や, ランアウトテーブルの長さに よって決定される長さの制限があり, コイルが小単重となっ てしまうことである。

\section{4 ストリップキャスト法}

ストリップキャスト法 ${ }^{11) ~ 14) ~}$ は, マグネシウム合金の溶湯 を直接板材として鋳造するもので, 薄板を直接鋳造できるこ

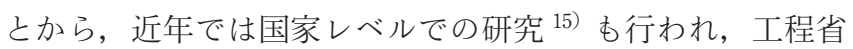
略によるコスト低減などが期待されている新しい技術である。 現在では, 板厚 $4.3 \mathrm{~mm}$, 板幅 $530 \mathrm{~mm}$ のコイル材が量産開始 され，コストダウンを含めて今後の展開が大いに期待できる。 また，一般的な重力鋳造や DC (半連続鋳造) と比較して冷 却速度が速く, 数百 $\mathrm{K} / \mathrm{s}$ にも達する ${ }^{16)}$ 。これは初期結晶粒径 の微細化之, $\mathrm{Mg}-\mathrm{Al}$ 系晶出物の微細分散が生じると報告され ており, よい特性を持つ母コイルを得られる可能性がある。 問題点としては, 回転ロール間で連続鋳造されるために, 特 に長手における凝固状態の均一化が困難之されている。また, 表面品質や晶出物を含めた介在物制御が当面の課題ともされ る。図 14 に各種法によって製作されたホットコイルの外観 を示す。手法によってサイズや表面状態はまちまちであるが, どれも実用に耐えるよい仕上がりとなっている。

\section{5 切断}

製造されたホットコイルは, 仕上げ圧延機の仕様や注文に 合せて耳や幅の切断が行われる。マグネシウム合金コイルの 切断はスリッ夕により行われる。スリッタは数枚の回転刃 (カッター) を組合せて，コイル材もしくは広幅材のトリミ ングや所定の幅に多条切断するための設備である。マグネシ ウムの切断は他実用金属と比較して困難である。それはマグ ネシウムの室温変形性の低さに起因し, 切断面のほとんどが 段差の大きい破断面之なるからである。特に厚板においてそ の影響が大きく, 最悪の場合, くさび状のクラックを発生さ せる場合むある。これらは仕上げ圧延時に耳割れに発展する 場合があり，幅歩留まり低下の原因となる。

\section{6 仕上げ圧延}

仕上げ圧延は，一般的に材料温度で約 $200^{\circ} \mathrm{C}$ 以上の熱間で

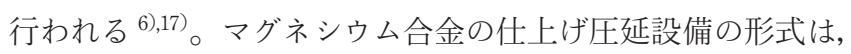
図 15 に示すようにシート圧延とコイル圧延の大きく 2 種類 に分類できる。シート圧延は, 短尺のシート状の素材を压延 機に供給して圧延する方式である。このシート圧延によって 多くの量産マグネシウム圧延板材が生産され, 実際, 海外で は $1000 \mathrm{~mm}$ を超える幅のシート圧延も行われる ${ }^{18)}$ など，世 界的にもマグネシウムの仕上げ压延においてポピュラーな方

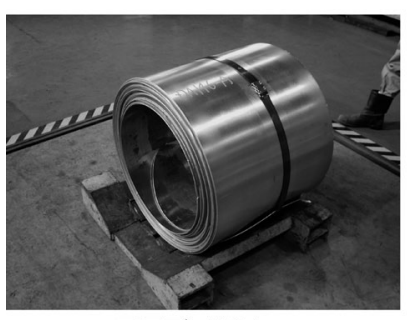

スラブ圧延材

t5.0mm $\times$ w570 $\mathrm{mm} \times$ coil (w720mmまで対応)

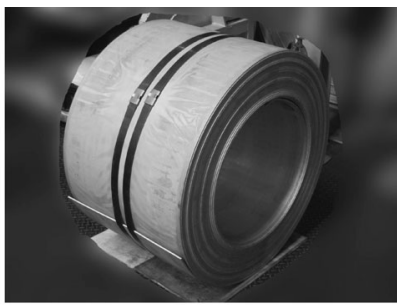

ストリップキャスト材 t4. $3 \mathrm{~mm} \times$ w530 $\mathrm{mm} \times$ coil

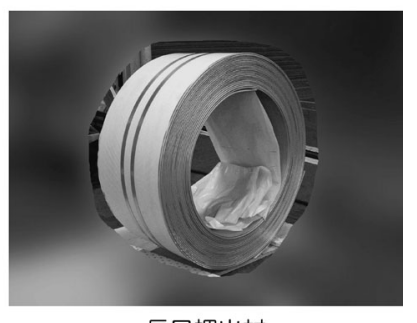

長尺押出材

t $4.5 \mathrm{~mm} \times$ w330 $\mathrm{mm} \times$ coil
図 14 各種法で製作された圧延用マグネシウム合金ホッ トコイルの外観
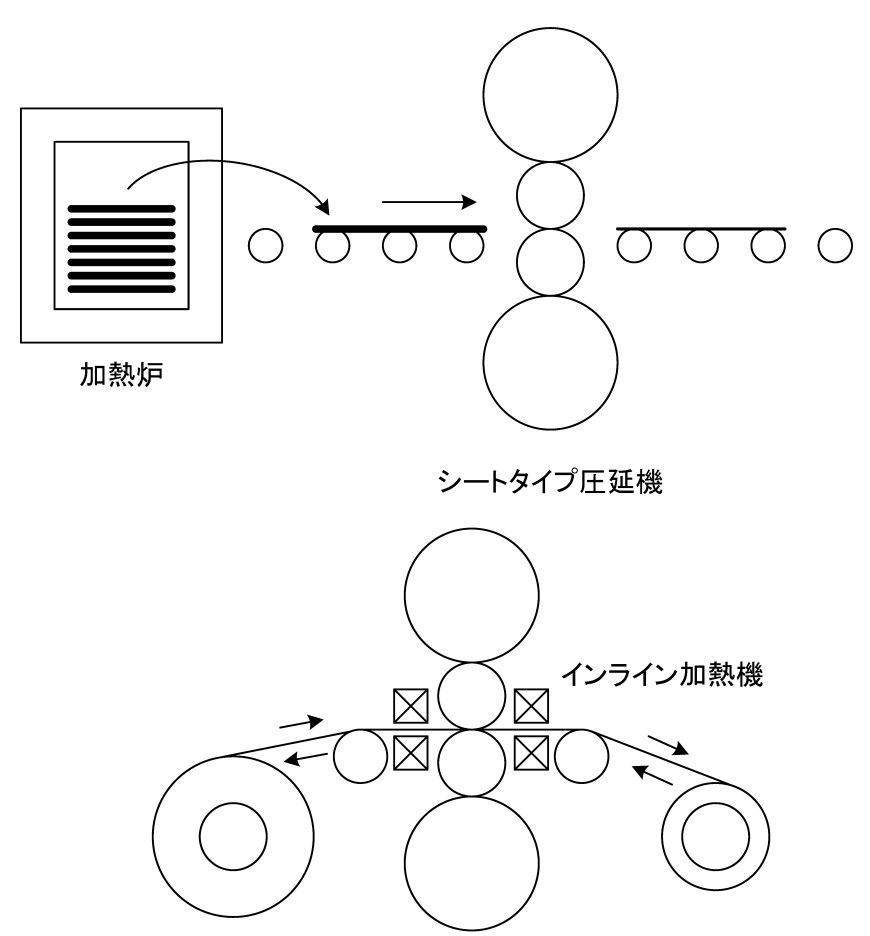

可逆式コイル圧延機

図 15 仕上げ圧延機の形式

法である。前述の通り, マグネシウム合金は粗圧延から仕上 げ圧延まで, 再結晶以上の温度で熱間圧延する必要がある が, シート圧延は, 圧延機とそれに付随した材料加熱用の加 熱炉があればよく, 各パス間で再加熱を行うことで, 効率よ く耳割れや板割れなどの温度低下による欠陥を排除して作業 が可能である。また, リール設備やコイル加熱炉などの大型 設備の導入が不必要であある。このような理由から，これま でのマグネシウム合金圧延板材は, ほとんどがシート状で供 給されてきた。しかしながら, 切り板状であるために, 平坦 
度制御性や形状制御性が悪く, 特に板の反りについては, 緎 細なロール直径のペア差管理や周速制御が必要となる。さら に生産性が劣ることと, 外因によるきずの発生確率が高いこ とが問題点として挙げられる。

コイル圧延は，コイル状の長尺母材を連続的に圧延してい く方法であり，薄板圧延の世界ではポピュラーな方法である。 マグネシウム合金の仕上げ圧延においても，圧延素材の温度 管理を行うことで, 他材料と同様のコイル圧延が可能である。 以下，このコイル圧延の工程説明を進める。

マグネシウム合金のコイル仕上げ圧延に用いられるのはシ ングルスタンド式圧延機が多い。ロール構成は $2 \mathrm{Hi} ， 4 \mathrm{Hi}, 6 \mathrm{Hi}$ が考えられ，形状制御はワークロールクラウンのほかに， ワー クロールベンディングやロールシフト機構により行われる。 圧延板材には高い平坦度が要求される場合が多く，熱間仕上 げ圧延のまま製品となる場合は，これら形状制御機構の使い こなしには注意が必要である。また，コイル圧延では，リー ルと呼ばれる巻取り装置を, ミルスタンド左右に設置してコ イルの巻出し, 巻取りを行う。このコイル圧延では, ロール とリール間で張力を付加することができる。圧延方向に対し て, 巻取り側の張力を前方張力, 巻出し側を後方張力とそれ ぞれ呼ぶ。図 16 は圧延圧力分布に及ぼす張力の影響 19）を示 したものである。図は軟鋼板の圧力分布を用いた例であるが， 張力を付加することで圧延圧力が低減する。具体的には，前 方張力でロール出口側が, 後方張力で入口側が減少し, 前後 同時付加で圧延圧力はさらに低下する。また，張力には， ロール前後での板の平坦度を保つ効果があり，特に広幅の薄 板圧延や箔（0.1 mm 以下）圧延では, 張力の付加なしに工業 的な生産は不可能に近い。

アルミニウムや銅等の非鉄金属の場合は, 歩留まり向上と 加工熱による温度上昇分の冷却などのために一方向へ圧延し てコイルを再び巻戻すワンウェイ圧延を行う場合があるが, マグネシウムの場合であ圧延したコイルの再加熱を行うため に，このワンウェイ圧延を用いることがある。この方法の場 合，1 パスごとに再加熱する必要があるために時間がかかる が，圧延機自体へオンラインの加熱装置などの設置の必要が なく, 比較的導入しやすい方法である。コイル圧延方法には, リバース (可逆) 圧延むある。リバース圧延はワンウェイ圧 延と違い，リールに巻かれた材料を可逆的に多数パスで圧延 する方法であって, 効率的なゲージダウンが行え, 量産に適 した方法である。ステンレス鋼や銅合金の薄板圧延ではリ バース圧延が一般的である。マグネシウムに多数パスリバー ス圧延を用いる場合，薄板で長尺の材料を圧延することとな るため，ロールバイト前後の温度变化を最小限にする必要が あり，ミルスタンド前後にインライン加熱装置を設置する等， 温度保持・管理を徹底しなければならない。図 17 にリバー ス圧延によって製作された AZ31B 合金コイルの外観を示す。 このように, マグネシウムでもアルミニウムや鉄鋼材料等と 同様の外観と形状を持った長尺コイル材の製作は可能であり, 図中のような板厚 $0.05 \mathrm{~mm}$ の箔材コイルの製造も可能である。

\section{7 表面仕上げ}

圧延材の表面には，酸化皮膜や圧延油，外部環境から巻込 まれた鉄の酸化物等が付着している。これらは腐食の起点と

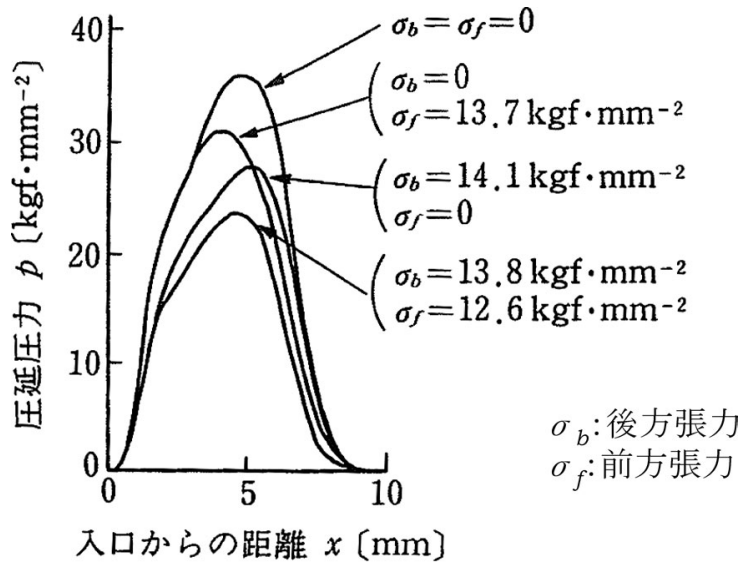

図 16 板幅中央の張力分布

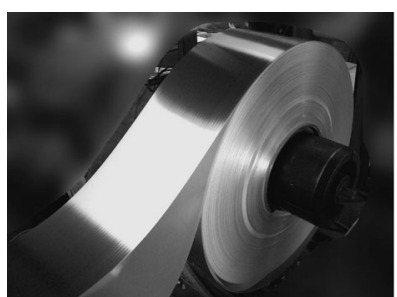

t0.6mm $\times{ }^{w} 306 \mathrm{~mm} \times$ coil

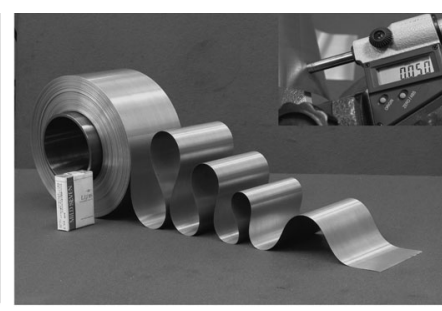

t0.05mm $\times{ }^{w} 110 \mathrm{~mm} \times$ coil
図 17 マグネシウム圧延コイルの外観

なるばかりか，後工程のプレスや表面処理工程に悪影響を及 ぼす。このため, これらを除去するための仕上げ工程が必要 である。マグネシウムの表面仕上げには, 酸洗処理や研磨処 理などがある。

酸洗処理は以下の工程をとる場合が多い。まず，脱脂工程 で表面を洗浄する。この場合，脱脂には鉄系材料と同様にア ルカリを用いる場合が多い。次に酸洗を行う。このとき使用 される酸は, 有機酸または無機酸, むしくはこれらの混合物 が適宜用いられる。その後，冷・温水洗浄後乾燥する。

研磨処理は，酸洗処理後もしくは圧延後そのまま行われ る。処理は安全性の面から湿式で行われ, 研磨ベルトや研磨 ホイルによって行われる。特に外装向けの素材の場合は, こ の研磨肌が製品意匠に直接影響を及ぼす場合が多く, 最近で は研磨工程が標準化する傾向にある。

\section{6. 圧延材の品質}

マグネシウムの冷間圧延が困難である理由は, 結晶構造と 集合組織に起因している。マグネシウムは結晶構造が稠密六 方構造であり, 軸比が最密充填構造に近く $\mathrm{c} / \mathrm{a} \fallingdotseq 1.623$ である。 図 18 にマグネシウム合金圧延材の $\{0001\}$ 不完全極点図を 示す。図には圧延のままの極点図と, それを $573 \mathrm{~K}$ で再結晶 熱処理したものとを示すが，マグネシウム合金圧延材の集合 組織は, 圧延〜熱処理の工程でほとんど変化しない。このこ とから，マグネシウム合金圧延板材は, 図 19 に示すように 六方晶の底面である $\{0001\}$ 面が圧延面に平行に配列する集 合組織を呈する 20),21)。このような圧延集合組織を有する場 合, 室温で活動が確認されるすべり系が底面や柱面の $\mathrm{a}$ 軸に 


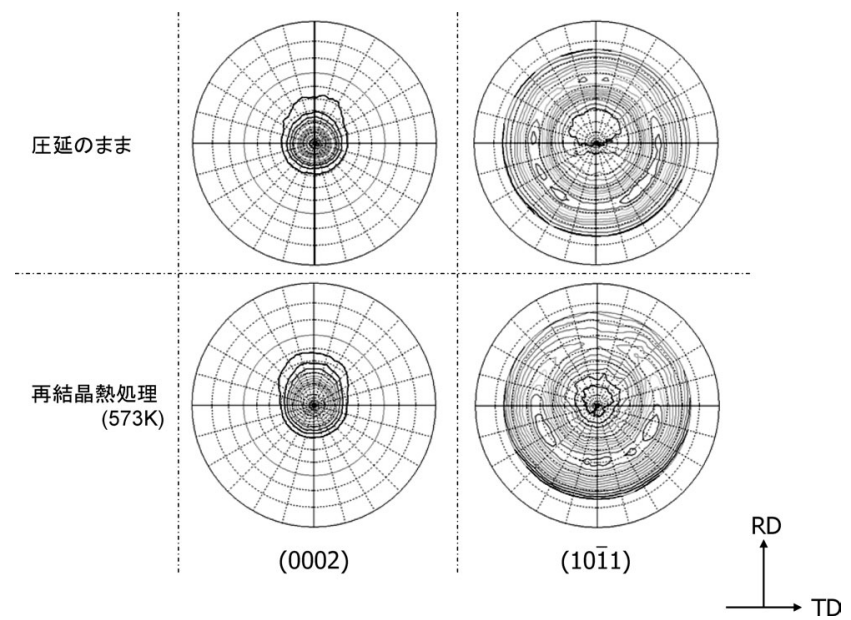

図 18 マグネシウム合金板材の不完全極点図

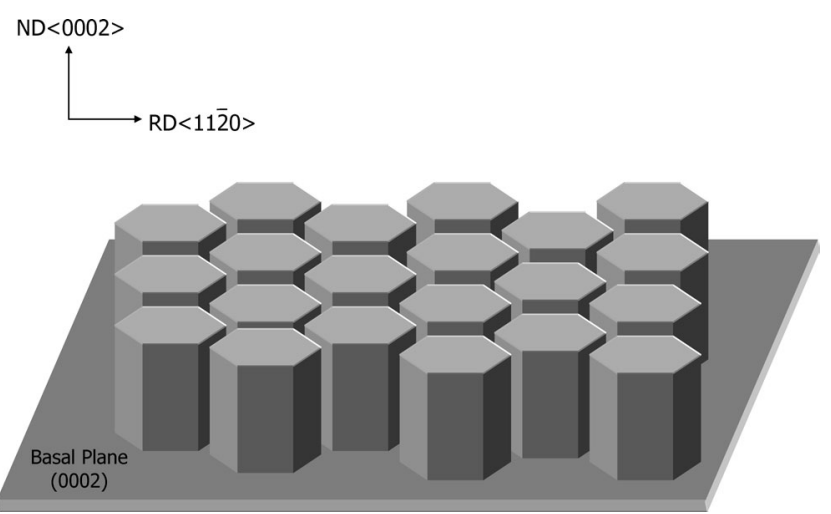

図 19 マグネシウム圧延板材結晶配列の概念図

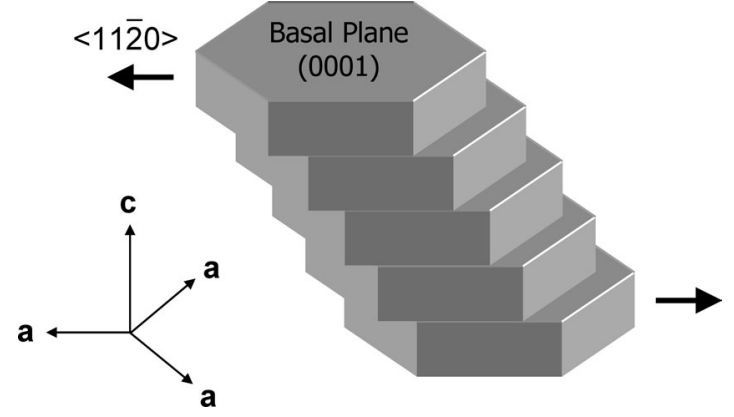

図 20 マグネシウム合金板材底面すべりの概念図
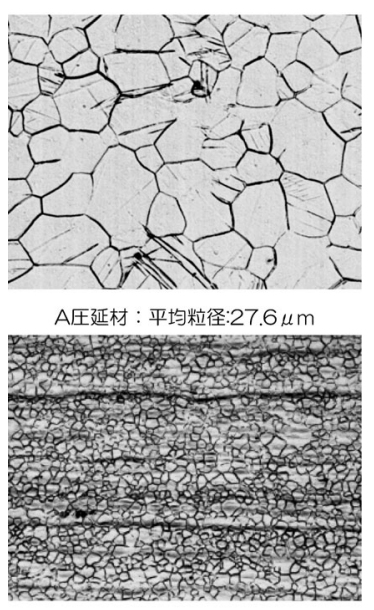

A圧延材 : 平均粒径: $27.6 \mu \mathrm{m}$

C圧延材 : 平均粒径: $4.9 \mu \mathrm{m}$

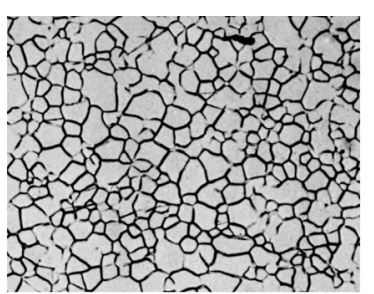

B圧延材 : 平均粒径: $12.2 \mu \mathrm{m}$

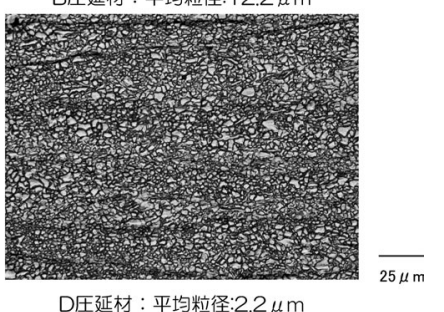

図 21 各種マグネシウム合金板材の結晶粒径比較（再結 晶熱処理材)

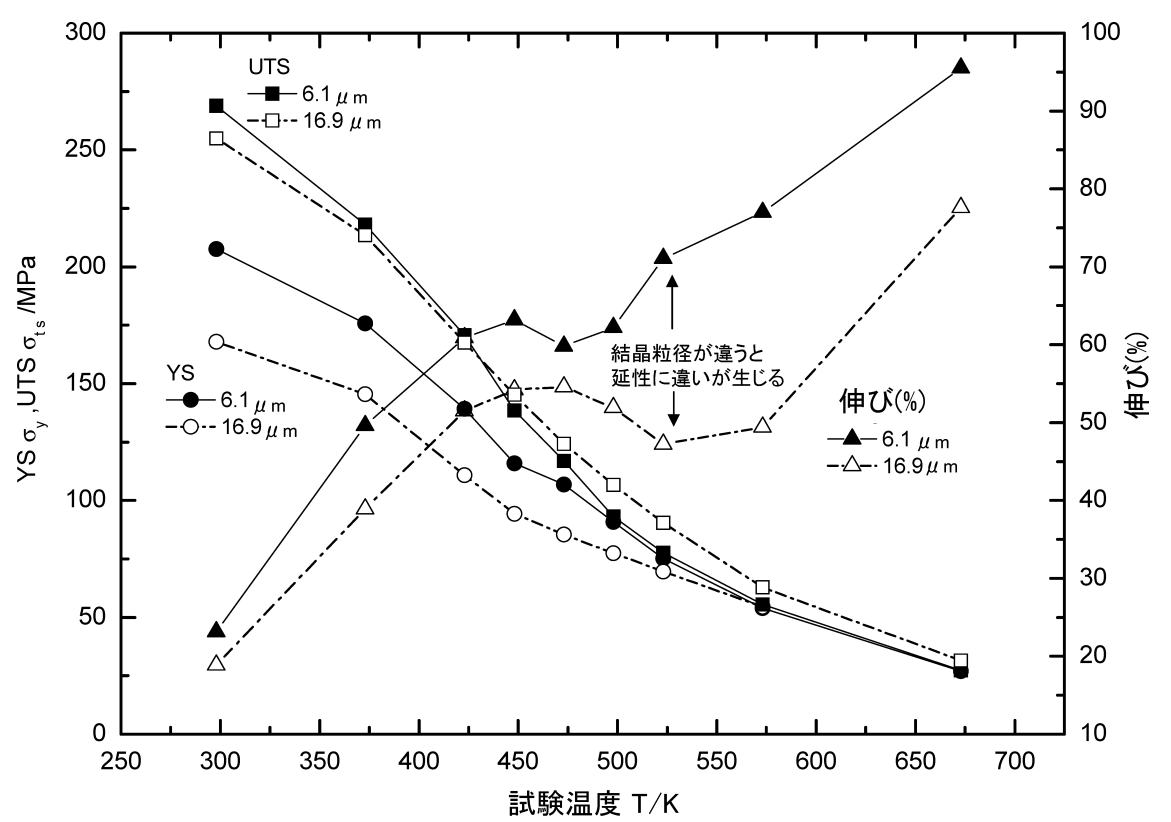

図 $22 \mathrm{AZ} 31 \mathrm{~B}$ マグネシウム合金圧延板材の機械的特性に及ぼす結晶粒径と温度の影響

平行方向しかないマグネシウムは，図20に示すように板厚 方向（c軸方向）へのひずみを生じることができない。よっ て，板厚減少を生じる形態の変形が著しく困難であり，圧延
を含めた室温での成形性は悪い。こういった要因から，マグ ネシウム圧延板材の成形加工はほとんどが熱間で行われる。 ゆえに，熱間成形に適した板材への特性制御が必要である。 


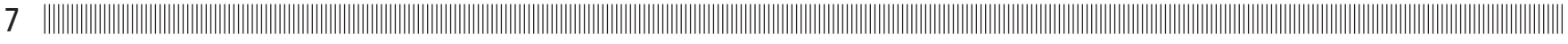

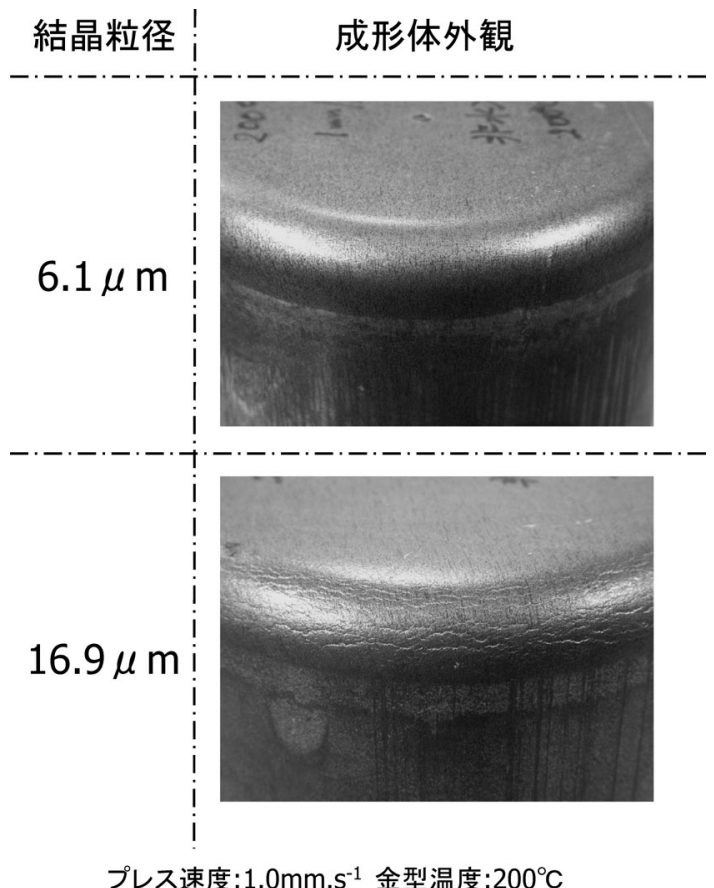

図 23 成形品の外観に及ぼす初期結晶粒径の影響

マグネシウム合金圧延材の品質として重要視されるのは, 主に以下の点である。

(1)結晶粒径の制御之微細化

(2)板厚精度，形状

(3)表面品質

\section{1 初期結晶粒径の影響}

マグネシゥム合金圧延材の機械的性質は，室温・熱間とも に，初期結晶粒径に大きく依存する。市販されているマグネ シウム圧延材の断面組織例を図 21 に示す。入手可能な市販 材であ，図に示すように結晶粒径が大きく異なる。試作材む 含めると 10 倍以上の結晶粒径差がある。熱間における破断 伸びと温度の関係に及ぼす初期結晶粒径の影響の一例を図 22 に示す 22)。実際にマグネシウム合金板材のプレス成形が行わ れる $200 \sim 300^{\circ} \mathrm{C}$ の温度範囲では，微細な結晶粒を持つ材料は 高い延性を示し，実際のプレス成形においても高い成形性を 示す。しかしながら，このような微細結晶をはじめとした， 高い熱間成形性を示す材料は，室温での強度試験において， 低い延性を示す場合が多い。このため，低い室温延性を理由 に試作初期段階で不採用になるケースがしばしばある。しか しながらこの点については，素材メ一カと成形加工メ一カと の綿密な打合せが必要であり，マグネシウムの熱間成形性を 構成する要因についての理解が特に必要である。

さらに，成形性だけでなく成形体の外観にも結晶粒径は大 きな影響を与える。図 23 に円筒絞り成形品の外観を示すが, 微細な結晶を持つ板材で成形した場合は非常に滑らかな外観 を示す。これに対して粗大粒の板材では, 成形体表面にくび れ状の模様が多数発生し大きく外観を損悋ている。このよう に板材の初期結晶粒径は品質に大きな影響を与える。特にマ グネシウム合金板材が熱間圧延によって製造されることを考 慮すると，圧延材の組織形成は圧延温度とパススケジュール

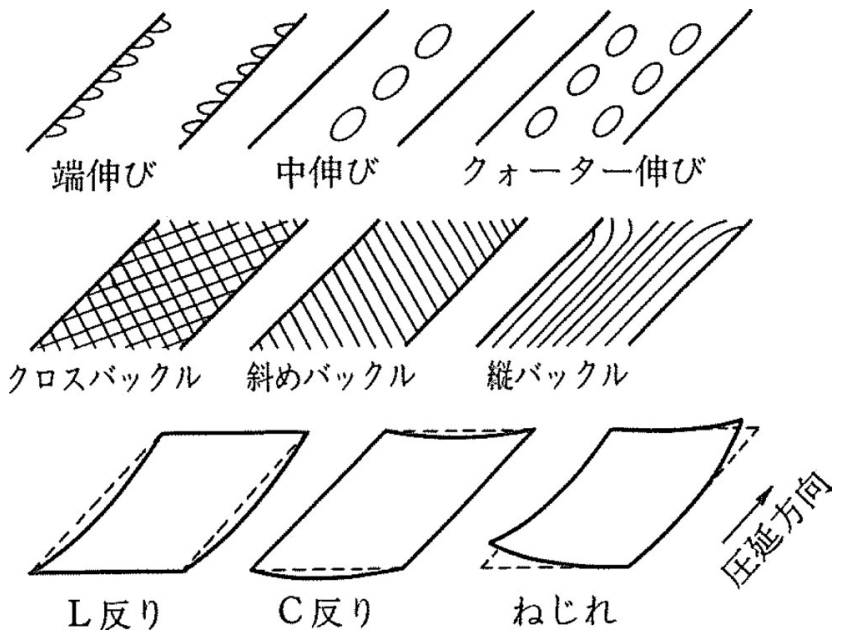

図 24 平坦度不良の種類

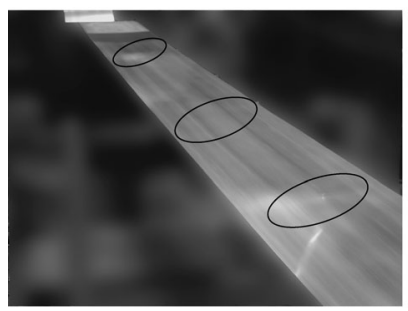

中伸びの例
端伸びの例

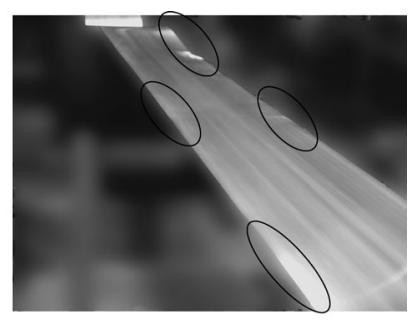

図 25 圧延材に発生した形状不良例

に大きく影響されると考えられる。しかしながら, 微細結晶 をすべての板厚範囲においてコイル全長で実現するのは困難 であるが, 圧延機の実操業可能範囲で最適化する必要があ る。

\section{2 表面品質}

成形性に関する品質とは別に表面性状に関しても高い品質 が求められている。現在では, アルミニウムや鉄鋼材料（又 テンレス鋼等）に近い外観品質が求められ, 内外装部品等使 用形態によらず研磨による最終仕上げが一般的になりつつあ る。これは後工程である表面処理〜塗装工程を考慮したもの で, 今後はさらに高い品質が求められることが予測される。 このような, 高い表面品質を得るためには，仕上げ圧延時で， ある程度の表面状態を確保する必要があるが，そのためには 母材であるホットコイルの表面品質からの管理が必要である。 圧延においてホットコイルに生じた欠陥を仕上げ圧延工程で 修正することは極めて困難であり, 場合によっては粗圧延前, 仕上げ圧延前に研磨工程が追加される。研磨方法はべルト研 磨やブラシ研磨などが，欠陥の程度によって適宜用いられる が, 仕上げ圧延前など長尺コイルに重研磨を行う場合, 表面 積が大きく，作業時間が長くなるばかりか歩留まりを大きく 低下させ，材料単価を大幅に上昇させる。できる限りホット コイル製作時の欠陥には注意をする必要がある。

\section{3 板の形状}

マグネシウムの圧延材においても, 平坦度は他材料同様に 重視される。圧延形状の制御には, 前述のイニシャルロール クラウンや圧延機の形状制御機構を活用して行われるが, 仕 
上げまで熱間で圧延されるマグネシウムでは, 特に熱膨張差 を考慮したクラウン設定が必要である。仕上げ圧延の段階で は, この板クラウン自体を大きく変化させることは困難であ り，無理に修正すると，図 24 に示すような，いわゆる中伸 びや耳波, 片伸びなどの形状不良の原因となる。図 25 に片 伸びと中伸びが発生した形状不良例を示す。写真では確認困 難であるが，この程度の形状不良が生じてしまうと, 製品と しての価值が著しく低下する。鉄鋼やアルミニウム，銅合金 などの圧延機では, オンライン用のプロフィル計が実用化さ れ活用されているが，このようなことから，ホットコイルの 段階で板クラウンの制御をしておく必要がある。マグネシウ ムのホットコイルは, 押出, スラブ圧延など複数の手法で製 造されるが，それぞれの手法ごとにクラウンの形成メカニズ ムが異なる。よって, 製品形状を視野に入れたホットコイル クラウンの検討が必要である。形状に及ぼすクラウンの影響 は他材料と同様であるが, 製法ごとの適正クラウンの明確な 指針がないのが現状である。

発生してしまった形状不良の修正方法として，一般的な ローラレベラによる矯正や，プレステンパ等も用いられる。 ローラレベラは連続的に配置された複数本のロール間で曲げ を行い, 形状を矯正するものである。使用できる下限ロール 径に制限があるほか, 強度の矯正を行った場合は, 機械的特 性が变化する可能性があるが，そのほかは鉄鋼材料などと同 様に処理することができる。一方, プレステンパは加熱矯正 法の一種であって, バッチ処理が前提となるために, シート 状の材料に用いられる。これは, 材料のクリープ变形によっ てひずみの除去と形状矯正するものであり，作業効率を考慮 して再結晶近傍の温度で処理する場合が多い。このプレステ ンパにおいても機械的特性が変化する場合が多く, 多くは強 度が低下する。

\section{7. おわりに}

マグネシウム合金板材は高価で加工が難しいというイメー ジがあるが，その特性を理解し，加工に最適な素材・成形条 件を選択すれば，プレス成形は極めて容易である。冷間で数 工程から十数工程にわたって行われる複雑な絞り成形であ, マグネシウムの熱間絞り成形では 1,2 工程で成形可能な例 がほとんどである。マグネシウム合金板材を用いたプレス成 形は, 薄肉化 (軽量化, 高密度化) への対応, 表面性状の高 さ等からノート型 PCのケーシング等に採用例が多くなって きた。また，マグネシウム圧延材でしか達成できない分野と
して, $0.1 \mathrm{~mm}$ 近傍の箔材の使用量が増加傾向にあり, スピー 力振動板や時計の針などに数多く採用例が見られるように なってきた。しかし，実際にはマグネシウム合金板材のプレ ス成形加工技術を持ち，量産可能なプレスメーカは国内でも 数えるほどしかなく，試作段階で頓挫する例む少なくない。 表面処理についても同様である。しかしながら，圧延板材を 用いた鍛造，打抜き，曲げ，絞り，およびその複合成形は， 量産技術として秀逸である。母材製作方法む多様化してきて おり, 今後は安価で高品質な板材の出現が見込める。更なる 使用量増加に期待する。

\section{参 考 文 献}

1）日本マグネシウム協会編：マグネシウム技術便覧，カロス出版， (2000), 73.

2）日本マグネシゥム協会編：マグネシウム技術便覧，カロス出版， (2000), 235.

3）日本塑性加工学会：板圧延, コロナ社, (1993), 14.

4）日本塑性加工学会：板圧延，コロナ社，（1993），113.

5）佐藤雅彦：塑性と加工，48 (2007), 373.

6）鑓田征雄, 橋詰 壮, 高松和也：塑性と加工, 48 (2007), $417-421$.

7）鑓田征雄, 橋詰 壮, 高松和也：塑性と加工, 47 (2006), 973-977.

8）日本マグネシウム協会編：マグネシウム技術便覧，カロス出版, (2000), 241.

9）日本マグネシウム協会編：マグネシウム技術便覧，カロス出版， (2000), 237.

10）村井 勉：マグネシウム合金の成形加工技術の最前線, シーエ ムシ一出版, (2005), 107-118.

11）渡利久規, 羽賀俊雄, 古閑伸裕：アルトピア, (2006), 16-21.

12) Y. Nakaura, A. Watanabe and K. Ohori: Mater. Trans., (2006), 17431749.

13）西田進一，本村 貢：軽金属，55（2005)，315-320。

14）松本和也, 鎌土重晴, 奥村勇人, 小島 陽：軽金属学会第 111 回秋期大会講演概要，(2006), 141-142.

15）松崎邦男, 初鹿野寛一：日本金属学会秋季講演大会概要, (2003)， 10.

16）中浦祐典, 杉本 丈, 渡部 晶：軽金属学会第 115 回秋期講演 大会概要， (2008)，34.

17）大口, 菅又 信, 金子純一, 久保田伸彦：塑性加工連合講演会 講演論文集，（2003），89-90.

18） P. Juchmann, S. Wolff: Proceedings of the 6th International Conference Magnesium Alloys and Their Applications, (2003), 1006-1012.

19）石川孝司：塑性と加工， 22 (1981)， 816.

20）金子純一, 菅又 信：日本金属学会誌，64 (2000), 141-147.

21）大年和徳, 勝田基嗣 : 軽金属, 51 (2001), 534-538.

22）佐藤雅彦, 加治屋強, 八代利之：軽金属, 54 (2004), 465471. 